\title{
COUNTER-INSURGENCY, ECOCIDE AND THE PRODUCTION OF REFUGEES Warfare As A Tool of Modernization
}

\author{
Jim Glassman
}

In a much-quoted article written during the height of the U.S. war in Vietnam, Harvard professor Samuel Huntington made the following observations:

The most dramatic and far-reaching impact of the war in South Viet Nam has been the tremendous shift in population from the countryside to the cities. In the early 1960s it was still accurate to speak of South Viet Nam as 80 to 85 percent rural. Today no one knows for certain the size of the urban population, but it is undoubtedly more than double and perhaps triple what it was a few years ago.

He went on to note that "The principle reason for this massive influx of population into the urban areas is, of course, the intensification of the war following the commitment of American combat troops in 1965." Deducing the implications of this for wars against rural revolutionary forces, Huntington suggested the need to qualify Sir Robert Thompson's claim that People's Revolutionary War is immune to the direct application of military force. "If the 'direct application of mechanical and conventional power' takes place on such a massive scale as to produce a massive immigration from countryside to city," Huntington argued, "the basic assumptions underlying the Maoist doctrine of revolutionary war no longer operate. The Maoist-inspired rural revolution is undercut by the Americansponsored urban revolution."

Buoyed by the fact that the National Liberation Front's 1968 Tet Offensive had not galvanized support for the revolution among Vietnamese urban dwellers, Huntington went on to summarize the implications of urbanization for the future of Vietnam:

Dr. Jim Glassman is associated with the Community Faculty of Metropolitan State University, St. Paul, Minesota, USA.

\begin{abstract}
[H]istory - drastically and brutally speeded up by the American impact - may pass the Viet Cong by. Societies are susceptible to revolution only at particular stages in their development. At the moment the rates of urbanization and modernization in the secure rural areas exceed the rate of increase in Viet Cong strength. At a time when the South Vietnamese Army is beginning to show signs of being able to operate on its own, The Viet Cong are becoming increasingly dependent on North Vietnam for manpoweraswell as supplies. A movement which once had the potential for developing into a" truly comprehensive revolutionary forcewith an appeal to both rural and urban groups could now degenerate into the protest of a declining rural minority increasingly dependent upon outside support.
\end{abstract}

In an absent-minded way the United States in Viet Nam may well have stumbled upon the answer to 'wars of national liberation.' The effective response lies neither in the quest for conventional military victory nor in the esoteric doctrines and gimmicks of counter-insurgency warfare. It is instead forced-draft urbanization and modernization which rapidly brings the country in question out of the phase in which a rural revolutionary movement can hope to generate sufficient strength to come to power. ${ }^{\text {I }}$

Huntington's remarks were rightly reviled by many critics who found his callousness to Vietnamese suffering and social dislocation appalling. But I want to suggest that his argument is quite important - both because it correctly identifies the demographic shifts which have undermined rural revolutionary movements in the past few decades and because it exemplifies the conscious appropriation of "forced-draft urbanization and modernization" as weapons in the arsenal of imperial warfare.
I want to go further than this, however, and point out that contrary to what Huntington coyly suggests, counter-insurgency "gimmicks" have themselves become part of the arsenal that helps produce urbanization. And I will show that ecological destruction is one substantive means by which U.S. planners have furthered their counterinsurgency goals. Thus, ecological destruction has become integrated into counter-insurgency as a method of producing the refugees necessary for effective control of the countryside by imperial powers and their local allies. The process, as I will show, is not one that either began or ended with the U.S. wars in Southeast Asia; but it is precisely because of this that Huntington's perspective is instructive, for counterinsurgency, rather than being seen as an esoteric bag of gimmicks, should be seen as a conscious application of force to the project of furthering the Eurocentric project of modernization. And in this sense, I will argue, the ecological destruction and social dislocation caused by counter-insurgency is contiguous with the much larger patterns of ecological destruction and social dislocation caused by the rise of capitalism from the sixteenth century onwards.

One of the most spectacular forms of environmental destruction visited on Vietnam by the U.S. military was the use of herbicides as part of the defoliation campaign. Use of defoliants was nothing new: the U.S. had used napalm extensively in Korea, for example. ${ }^{2}$ In Vietnam, however, the use of new and experimental chemical defoliants was intensified. During August 1961, in the context of the counter-insurgency war and the project for rural "Pacification," the U.S. began using herbicides on an experimental basis. Both forests and 
food crops were targeted, with the purpose being to deny the rural population cover and subsistence so that they could be forced either to urban centers or to the concentration camps euphemistically dubbed "strategic hamlets." As the official U.S. Air Force history puts it in describing the Joint Chiefs of Staff (JCS) position at the end of 1967, "[a]fter crops had died in target areas, groups of civilians had moved to areas under government control, further aggravating the guerrilla's manpower problems." ${ }^{3}$ Furthermore, as the JCS' counter-insurgency head observed in December 1967, "[a]lthough the policy to create refugees for military purposes does not, in so many words, appear in any MACV [Military Assistance Command, Vietnam] document, the necessity is openly recognized as a realistic requirement ...."4

The herbicide program, Operation Ranch Hand, operated with the catchy motto "Only We Can Prevent Forests," and it did much to live up to this motto: between the beginning of 1962 and the beginning of 1970, the U.S. dropped one hundred million pounds of herbicides on over four million acres of South Vietnam. ${ }^{5}$ The combined effects of napalm, white phosphorous and Agent Orange (comprised of 2,4-D and 2,4,5-T) were environmentally devastating and led to the coining of the term "ecocide." Between one-fourth and one-half of Vietnam suffered defoliation at some point during the war. As much as 41 percent of South Vietnam's mangrove forests were denuded. Other scorched earth tactics included direct attacks on animals and the use of giant bulldozers, "Rome Ploughs," to clear forests. 6

The environmental destruction caused by this policy of "drying up the sea to catch the fish" is a legacy with which Vietnam continues to live.

One expert in agricultural economics who had lived in Vietnam for many years told me that the flooding of rice lands continues to be a major problem in Vietnam because so many hillsides are denuded of foliage that rainfall is not absorbed adequately and rushes down onto the plains. 7 A report on Vietnam issued by the International
Union for the Conservation of Nature says of the environmental situation that "much of the damage can probably never be repaired." 8

The success of U.S. warfare in swelling urban centers with refugees also had social costs: a whole generation of Vietnamese youth grew up without learning farming skills or developing other abilities that were essential to traditional Vietnamese society. Meanwhile a culture of prostitution, drug addiction, racketeering and petty commerce blossomed, leaving revolutionary Vietnam a social reconstruction project every bit as daunting as its task of environmental restoration. ${ }^{9}$ But the dislocations were not seen by U.S. planners as a reason to reconsider either strategy or tactics; rather, the dislocation of the rural population become a central ingredient in fighting counter-insurgency wars.

The herbicide program was by no means the only (or even the major) component of this approach. In fact, RAND corporation studies conducted during the 1960s suggested abolishing the herbicide program in Vietnam, arguing that it was often counterproductive because it alienated peasants from the South Vietnamese government and the U.S. military. The U.S. military rejected these arguments and continued using herbicides until the Nixon administration finally ended the program because it left insufficient supplies for U.S. domestic users. ${ }^{10}$ But whatever the actual impact of herbicides on peasant attitudes and behavior, "forced-draft urbanization and modernization" was also produced simply by massive bombing, which left enormous environmental damage in its own right. "1 In Cambodia, to cite another case for purposes of comparison, bombing by itself led to much of the urbanization that occurred during the early to mid-1970s, when Phnom Penh's population grew from about half a million to over two million. ${ }^{12}$

In Vietnam, the effects of bombing cannot be disentangled from all the other tactics used to create new demographic realities, so the three million refugees created by the end of 1967 and the ten million created by 1973 cannot be seen narrowly as the result of one or another form of warfare. ${ }^{13}$ But the proportional responsibility does not matter. What matters is that all tactics were either explicitly or implicitly environmentally destructive, all either explicitly or implicitly aimed to create refugees from rural areas and all were consciously adopted precisely because they either actually did or were thought to successfully undermine rural support for revolution.

The success of environmentally destructive counter-insurgency tactics in creating refugees - if not necessarily in creating allies in the counter-insurgency struggle - helps account for its continuing role in U.S. warfare. U.S. policies in Central America during the 1980s have often been compared to earlier policies in Southeast Asia and justifiably so. ${ }^{14}$ In El Salvador, for example, the U.S.-backed regime used napalm and other defoliants extensively throughout the 1980s, leading to the destruction of large amounts of forest. Fragmentation and incendiary bombs also caused severe environmental damage. According to a Salvadoran priest, "these bombs leave craters fifteen feet deep and sever trees too thick to encircle with one's arms." In some regions, bombing created a food crisis, causing shortages of corn, beans and rice. ${ }^{15}$

The destruction of Salvadoran forest as counter-insurgency policy exacerbated the already severe deforestation that has occurred over the years as a consequence of U.S. and Salvadoran "development" policies, which have emphasized export crops like cotton and coffee. ${ }^{16}$ Over 95 percent of El Salvador's original tropical deciduous forests are gone and only 7 percent of the country has forest cover today. ${ }^{17}$ Meanwhile, loss of foliage on hillsides has led to severe erosion, which affects more than 77 percent of the country. Topsoil loss reaches rates of 20 percent annually. ${ }^{18}$

The war between indigenous guerrillas and the U.S.-backed Salvadoran government produced a tidal wave of refugees along with (and because of) this environmental 
destruction, but most of these refugees have not gone to San Salvador. Rather, they have migrated within the country or left entirely: displaced persons within the country have been estimated at 200,000 to 500,000 ; as many as 750,000 Salvadorans fled to the United States, with another 250,000 fleeing to Mexico and 50,000 to 100,000 going elsewhere in Central America. ${ }^{19}$ This means that up to a fifth or more of the Salvadoran population has been displaced by war and environmental destruction, a higher proportion than the Vietnamese displaced at the height of the Vietnam war. ${ }^{20}$ Counter-insurgency has not contributed as much to urbanization and modernization in El Salvador as it did in Vietnam; but it has helped "dry up the sea" in which the Salvadoran rural insurgency hoped to swim, thus denying the rebels the possibility of a military victory.

In Guatemala, to cite one more case, in an effort to quell the country's insurgency, U.S.-backed armed forces destroyed forests, fields and livestock, displacing one million Guatemalans. Fire is used to destroy the environment and displace people. Most of the refugees are of Mayan Indian ancestry and the army intentionally targets their corn crops for destruction because, along with destroying a vital food source, this practice undermines the Indians' psychological resistance by breaking an age-old and symbolically loaded bond - based on the production and reproduction of life - between their communities and the earth. Crop destruction also leads to serious erosion problems and renders agricultural land useless. ${ }^{21}$

The army relocates the refugees into "model villages" reminiscent of Vietnam's "strategic hamlets."22 Others leave the country entirely, many heading to Mexico, the United States or Canada and some 40,000 inhabiting UNsponsored camps. ${ }^{23}$

Not satisfied with the "success" of its counter-insurgency campaign, the U.S. developed a new program in 1987 and 1988, invoking the "War on Drugs" to justify spraying vegetated areas in
Guatemala with glycophosphate herbicides such as Round-Up - despite the fact that Guatemala does not appear on the UN's list of drug-growing nations. ${ }^{24}$ The real target of the spraying, the Guatemalan government later admitted, was not marijuana or poppy but rather the insurgents. ${ }^{25}$ In the meantime, the sprayings produced human deaths, deformed children, ulcerations of the mouth and throat from drinking sprayed water sources, an increase in infant mortality, deaths of whole herds of livestock as well as honey bees and scores of endangered quetzals, destruction of an entire season of corn and tomato crops and widespread defoliation. ${ }^{26}$ Whether this use of toxic chemicals against a largely contrived pharmacological threat will also result in more human displacement, more urbanization, or more "modernization" remains to be seen; but the production of refugees through a herbicidal "War on Drugs" would certainly not be inconsistent with the modus operandi of U.S. counter-insurgency as it has been practiced in Central America and elsewhere. ${ }^{27}$

On a moral level, the appropriate response to the social and environmental destruction caused by counterinsurgency tactics is repugnance and political opposition. But on a more analytic level I would argue that it is important to frame opposition to the production of refugees through ecocide with an understanding of the ways in which counter-insurgency fits into the context of development as it has been carried out by U.S. and other Western forces. For far from being an anomolous feature of development, ecocide and "forced-draft urbanization" represent simply the acceleration of tendencies that are already present in the broad process of modernization as they have evolved over the centuries. Thus, the suggestions of Samuel Huntington and other U.S. planners, far from demonstrating mere moral depravity, demonstrate a sharpened consciousness of the developments that have propelled capitalism and simultaneously undercut - particularly in recent decades - the more agrarian alternatives to it which had been posited in much of the "Third World."

A starting point for this line of analysis is to acknowledge that all transitions from one form of society to another involve at least ecological transformation and most likely, given the trends of history over many millenia, environmental destruction. The enclosure of the commons during the long centuries of capitalism's rise in England transformed much farmland into pasture for sheep..$^{28}$ The "Columbian exchange," which occurred in 1492 and subsequently, brought new crops, animals and diseases to the Americas and others back to Europe, Asia and Africa, set off a quite traumatic transformation of American ecology and societies. ${ }^{29}$ The Europeans who killed American Indians and displaced them from their homelands simultaneously transformed the natural environment, often tearing down forest and transforming wooded areas and grasslands into farmland. ${ }^{30}$

Furthermore, crop destruction has always been an integral part of the warfare by which subjugation and displacement of indigenous peoples is promoted. Seventeenth-century North American colonists destroyed Indian corn and other crops as a routine part of warfare. ${ }^{31}$ Destruction of a basic food source for the Plains Indians, the bison, was accomplished later through both conscious and unconscious means. ${ }^{32} \mathrm{Kit}$ Carson destroyed the food supplies of the Dineh (Navajo) people as he waged war against them during the 1860 s, earning their ultimate enmity by destroying their peach orchards - more than five thousand trees..$^{33}$ In such developments, ecological transformation and the uprooting of an indigenous population resistant to modernization were always implicitly intertwined.

In the twentieth century, the interconnections between environmental destruction and population transfer simply became more plain - in large part because more advanced technologies of destruction (both military and nonmilitary) made the 
possibility for massive environmental destruction and population dislocation more obvious. Counter-insurgency planning, which incorporates ecocide as a tactic, merely acknowledges this obvious connection and attempts to spur on the generation of refugees.

In a sense, then, one could say that the reflections of Samuel Huntington and those like him show an awareness of trends that facilitate the capitalist development project: uprooting of resistance to modernization by warfare and concomitant environmental transformation has been a trend of history for centuries; urbanization and modernization have been trends within the capitalist world economy for at least the past one hundred years. The application of military power to the furthering of these trends, then, is very much like swimming downstream. For those who have attempted to stem the tide of this sort of rural social dislocation and environmental destruction, on the other hand, the situation has been much more vexed. Maoist revolutionaries, who saw wars of national liberation succeeding because of the strength of peasant resistance rather than merely because of the strength of the industrial proletariat, have proven to be right - in their time. But Huntington may well have been correct when he argued in 1968 that their time is short and passes with the demographic transformations that turn formerly rural societies into urban ones. ${ }^{34}$

From this perspective, the production of environmental refugees through ecocide is not something that can be fought merely by opposition to militarism. Rather, the roots of social and environmental transformation in the development of capitalism must be addressed. The story of counterinsurgency as a tool for producing environmental refugees is only the history of capitalism "drastically and brutally speeded up." Eurocentric modernization has produced environmental destruction and refugees for the past 500 years; counterinsurgency and its unique forms of ecocide are only an intensification of the old battle using newer weapons.

\section{References}

1. Samuel Huntington, "The Bases of Accommodation," Foreign Affairs 46 (1968): 648-652

2. See, e.g., Bruce Cumings, Origins of the Korean War. Volume II. The Roaring of the Cataract, 1947-1950 (Princeton: Princeton University Press, 1990): 706-7.

3. GabrielKolko, Anatomy of a War: Vietnam, the United States and the Modern Historical Experience (New York: Pantheon, 1985): 144,239

4. Ibid.: 239.

5. Marilyn B. Young, The Vietnam Wars, 1945-1990 (New York: Harper Collins, 1991): 82. Also see Wiiliam Appleman Williams, Thomas McCormick, Lloyd Gardner and Walter LaFeber, eds., America in Vietnam : A Documentary History (Garden City, New York: Anchor Press/Doubleday, 1985): 302.

6. Militarization: The Environmental Impact, The Environmental Project on Central America (EPOCA): 3.

7. Don Luce, in a talk given to Iowa City, Iowa, during 1988.

8. EPOCA, op. cit. For a description of efforts to reconstruct Vietnam environmentally since the war, see Elisabeth Kemf, Month of Pure Light: The Regreening of Vietnam (London: The Women's Press, 1990).

9. See Judy Chu, "The Trauma of Transition: Southeast Asian Refugees in America," in G.M. Nishinaka, ed., Bridging Cultures: Southeast Asian Refugees in America: Social Work with Southeast Asian Refugees (Los Angeles: Special Service for Groups: Asian American Community Mental Health Training Center, 1983).

10. Kolko, op. cit.: 145; Young, op. cit.:190-91

11. On the destruction from bombing see EPOCA, op. cit. and Kemf, passim. Also see Joel Charney, Obstacles to Development in Vietnam and Kampuchea: US Embargoon Humanitarian Aid (Boston: Oxfam America, 1984).

12. On Cambodia, see Michael Vickery, Cambodia, 1975-1982 (Boston: South End Press, 1984); Kampuchea: Politics, Economics and Society (London: Frances Pinter, 1986); Ben Kiernan and Chantou Boua, Peasants and Politics in Kampuchea, 1942-1981 (London:Verso, 1985).

13. Refugee figures are from Kolko, op. cit ,: 239; Chu, op. cit.
14. See e.g., Bill Weinberg, War on the Land: Ecology and Politics in Central America (London: Zed Books, 1991): 58-64. Also see the 1985 Congressional report by U.S. Representatives Hatfield, Leach and Miller, "U.S. Military Assistance to El Salvador."

15. EPOCA, op. cit.: 4

16. See Weinberg, op. cit.: chap.9; EPOCA, El Salvador:Ecology of Conflict.

17. EPOCA, El Salvador: 2.

18. Ibid.; Tom Barry, Central America Inside Out (New York: Grove Weindenfield, 1991): 196.

19. Barry, op. cit.: 194

20. EPOCA, Militarization: 4.

21. Ibid.: 5

22. Ibid.

23. Barry, op. cit.: 264.

24. Ibid.: 266; EPOCA, Guatemela: A Political Ecology, p.13; Weinberg, op. cit.: 53.

25. Weinberg, op. cit.: 53

26. EPOCA, Guatemela: 13

27. Use of defoliants in the "War on Drugs" is now expanding in Andean countries such as Colombia and Peru where insurgencies still threaten the stability of U.S.-backed regimes. See, e.g., Latin American Weekly Report (20 February 1992).

28. A classic and still useful discussion of this issue is R.H. Tawney's The Agrarian Problem in the Sixteenth Century (New York: Harper \& Row, 1967).

29. See Alfred W. Crosby, The Columbian Exchange: Biological and Cultural Consequences of 1492 (Westport, Connecticut: Greenwood Press, 1972).

30. For a useful overview of this process, see Joseph M. Petulla, American Environmental History (Columbus: Merrill Publishing, 1988): parts I \& II.

31. See, e.g., Francis Jennings, The Invasion of America: Indians, Colonialism and the Cant of Conquest (New York: W.W. Norton, 1976): 153, 210, 211, 321.

32. A standard account of this is Dee Brown's Bury My Heart at Wounded Knee (Toronto: Bantam Books, 1972).

33. Ibid.: 27

34. One author, who also seems to feel that revolutionary struggles such as the one in Vietnam have passed their historical moment, is Melanie Beresford who would disagree both in analysis and in spirit with virtually everything else that Huntington has to say). See her Vietnam: Politics, Economics and Society (London: Pinter Publishers, 1988). 